\title{
Effect of hydrogenation of carbon atom on its deposition on graphene
}

\author{
Kh. I. Jabborov ${ }^{\dagger, 1,3}$, A. N. Ulukmuradov², I. D. Yadgarov ${ }^{3}$, N. I. Ibrokhimov ${ }^{4}$ \\ †xayitmurodjon@mail.ru
${ }^{1}$ Research Institute for the Development of Digital Technologies and Artificial Intelligence, Tashkent, 100125, Uzbekistan
${ }^{2}$ Tashkent Institute of Textile and Light Industry, Tashkent, 100100, Uzbekistan
${ }^{3}$ Arifov Institute of Ion-Plasma and Laser Technologies, Uzbekistan Academy of Sciences, Tashkent, 100125, Uzbekistan
${ }^{4}$ Ferghana polytechnic institute, Ferghana, 150107, Uzbekistan

This article discusses the possibility of graphene functionalization by the deposition of carbon atoms with different degrees of hydrogenation and the effect of hydrogenation on the probability of precipitation using computer simulation. According to the results of computer simulation, the binding energy of the single carbon atom, methine, methylene and methyl is more than $1 \mathrm{eV}$. This corresponds to chemisorption, which means that the chemical bonds are generated due to unpaired valent electrons of the incident particles and defect-free graphene. Methane does not have unpaired valent electrons and in the range of investigated deposition energies its chemisorption on graphene is not observed. The free carbon atom with various degrees of its hydrogenation is considered: methane $\mathrm{CH}$, methylene $\mathrm{CH}_{2}$, methyl $\mathrm{CH}_{3}$ and methane $\mathrm{CH}_{4}$. It is established that if the deposited particles $\mathrm{C}, \mathrm{CH}, \mathrm{CH}_{2}$ and $\mathrm{CH}_{3}$ form a bound state with graphene, these particles are located near the characteristic points with a different probability of location above graphene at these points. The processes of deposition of hydrogenated and non-hydrogenated carbon atoms with kinetic energies of 1.0, 1.2, 1.5, 2.3 and $3.1 \mathrm{eV}$ on graphene are studied. It is found that the processes of deposition of non-hydrogenated and hydrogenated carbon atoms on defect-free graphene depend on the degree of hydrogenation of the carbon atom: the more hydrogenated the carbon atom is, the less its probability of chemisorption on graphene. Methane, as a fully hydrogenated carbon atom, does not chemisorb on graphene at deposition energies from 1 to $3.1 \mathrm{eV}$. It is also observed that the maximum probability of chemisorption of $\mathrm{C}, \mathrm{CH}, \mathrm{CH}_{2}$ and $\mathrm{CH}_{3}$ on graphene took place at deposition energy of about $2.3 \mathrm{eV}$.

Keywords: carbon atom, hydrogenation, defect-free graphene, deposition energy, computer simulation, Brenner potential, chemisorption probability, molecular dynamics.

\section{Влияние гидрирования атома углерода на его осаждение на графен}

\author{
Жабборов Х. И. ${ }^{\dagger, 1,3}$, Улукмурадов А.Н. ${ }^{2}$, Ядгаров И.Д. ${ }^{3}$, Иброхимов Н. И. ${ }^{4}$ \\ ${ }^{1}$ Научно-исследовательский институт развития цифровых технологий и искусственного интеллекта, \\ Ташкент, 100125, Узбекистан \\ ${ }^{2}$ Ташкентский институт текстильной и легкой промышленности, Ташкент, 100100, Узбекистан \\ ${ }^{3}$ Институт ионно-плазменных и лазерных технологий имени У.А. Арифова, Ташкент, 100125, Узбекистан \\ ${ }^{4}$ Ферганский политехнический институт, Фергана, 150107, Узбекистан
}

В этой статье обсуждается возможность функционализации графена осаждением атомов углерода с разной степенью гидрирования и влияние гидрирования на вероятность осаждения с использованием компьютерного моделирования. Согласно результатам компьютерного моделирования, энергия связи одиночного атома углерода, метина, метилена и метила составляет более 1 эВ. Это соответствует хемосорбции, что означает, что химические связи образуются за счет неспаренных валентных электронов падающих частиц и бездефектного графена. Метан не имеет неспаренных валентных электронов и в исследованном диапазоне энергий осаждения его хемосорбция на графене не наблюдается. Рассматривается свободный атом углерода с различной степенью его гидрирования: метан $\mathrm{CH}$, метилен $\mathrm{CH}_{2}$, метил $\mathrm{CH}_{3}$ и метан $\mathrm{CH}_{4}$. Установлено, что если осаждаемые частицы $\mathrm{C}, \mathrm{CH}_{2} \mathrm{CH}_{2}$ и $\mathrm{CH}_{3}$ образуют связанное состояние с графеном, то эти частицы располагаются вблизи характерных точек с разной вероятностью нахождения в этих точках над графеном. Изучены процессы осаждения гидрированных и негидрированных атомов углерода с кинетическими энергиями 1.0, 1.2, 1.5, 2.3 и 3.1 эВ на графен. Установлено, что процессы осаждения 
негидрированных и гидрированных атомов углерода на бездефектный графен зависят от степени гидрирования атома углерода: чем более гидрирован атом углерода, тем меньше вероятность его хемосорбции на графене. Метан, как полностью гидрированный атом углерода, не хемосорбируется на графене при энергиях осаждения от 1 до 3.1 эВ. Также наблюдается, что максимальная вероятность хемосорбции $\mathrm{C}, \mathrm{CH}, \mathrm{CH}_{2}$ и $\mathrm{CH}_{3}$ на графене имеет место при энергии осаждения около 2.3 эВ.

Ключевые слова: атом углерода, гидрирование, бездефектный графен, энергия осаждения, компьютерное моделирование, Потенциал Бреннера, вероятность хемосорбции, молекулярная динамика.

\section{Introduction}

The defect-free graphene is a two-dimensional hexagonal carbon crystal lattice with a distance between the nearest atoms of $1.42 \AA$ represents a very special object [1]. The structure of graphene is very stable at given conditions with a very strong interaction between each carbon atom $[2,3]$. Each carbon atom in graphene is bonded to three adjacent carbon atoms through a $\sigma$-bond. The remaining $p$-electrons most likely form a $\pi$-bond with the surrounding atoms, and the bonding direction is perpendicular to the graphene plane. When the electrons of graphene move in the internal orbit, there is no scattering phenomenon due to the interference of inclusion atoms or lattice defects $[4,5]$.

At the same time, the adsorption of additional atoms or molecules to the defect-free graphene changes and extends its properties. Graphene with such additional objects is functionalized graphene. To date, graphene was studied to be doped with various heteroatoms to obtain better work functions for the field-emission [6] or high-performance catalytic activator [7] and perfect electrode material [8]. Graphene can be functionalized with metal oxides to change the surface properties of graphene for wide applications such as nano-devices [9] and efficient catalysts for reactions [10].

Generally, nanotechnology always proves that it can control the assembling processes of different chemical structures at nanoscale materials [11]. Therefore, nanomaterials are often observed to emerge among the focus of advanced research $[12,13]$. Graphene can be functionalized by attaching carbon atoms, dimers and trimers, $\mathrm{CH}_{4}$ and $\mathrm{CO}_{2}$ molecules [14-18]. Recently, numerous research has been conducted on graphene doped with other elements, molecules, or organic materials [19-22]. Doping is the most feasible method to control the semiconducting properties in the conventional semiconductor community. The B and $\mathrm{N}$ atoms are the natural candidates for doping in graphene because of their similar atomic size as that of $C$ and of their hole acceptor and electron donor characters for substitutional $\mathrm{B}$ - and N-doping, respectively. The substitutional doping is also a useful method to open bandgap of graphene as proved by the theoretical work about $\mathrm{B}-, \mathrm{N}$ - and $\mathrm{Bi}$-doping in graphene [23].

An attractive material for hydrogen storage is graphene [24-26], which comprises single sheets of carbon allotropes in a 2D hexagonal lattice with a large surface area. The reversible hydrogenation/dehydrogenation cycles in graphene [26], along with the fact that it can be easy modified, makes it a potential candidate for the hydrogen storage application [27].

In the present work, molecular dynamics simulation is applied to study the functionalization of graphene by depositing carbon atoms with different degrees of hydrogenation on graphene as well as the effect of hydrogenation on a deposition probability.

\section{Simulation details}

The initial structures are obtained with the help of the JMOL program and by the energy minimization method the structure given into thermodynamic equilibrium. The calculations used the second generation Brenner potential (REBO), which can very well describe carbon and hydrogencarbon structures [28]. As was shown in [29-32], this potential describes very well the carbon-carbon interaction. Its fitness in describing hydrocarbon systems is shown. The binding energy, the bond length and the bond angles of some hydrocarbons as calculated by the modified Brenner potential agree very well with available experimental and other theoretical data. The computer models of the free carbon atom with different degrees of its hydrogenation, namely, methine $\mathrm{CH}$, methylene $\mathrm{CH}_{2}$, methyl $\mathrm{CH}_{3}$, and methane $\mathrm{CH}_{4}$ are built. An example of all the considered molecules adsorbed on graphene is presented in Fig. 1. According to the computer simulation, the distance between atoms in methine is $1.09 \AA$, cohesion energy of hydrogen atom is $2.263 \mathrm{eV}$. In

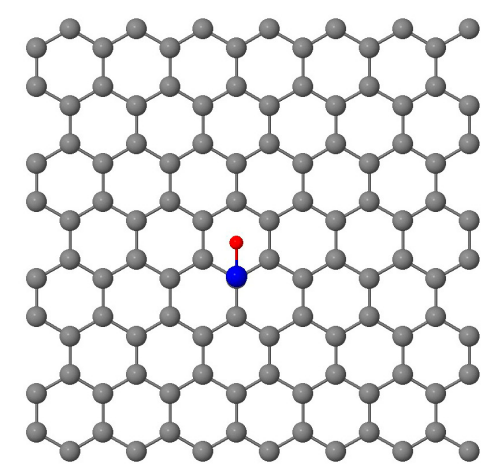

a
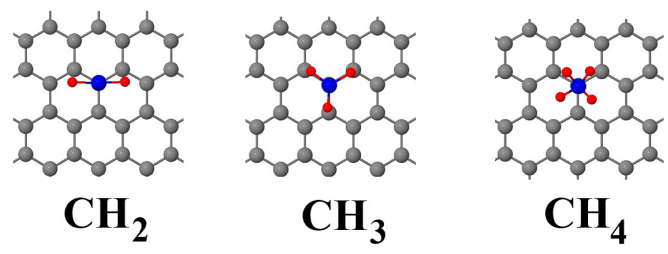

$\mathrm{b}$

Fig. 1. (Color online) Graphene square-shaped defect-free simulation cell with the absorbed hydrogen atom (methine) (a). Part of the simulation cell with methylene, methyl and methane. The gray circles are carbon atoms; the red circles are hydrogen atoms and blue circle is the carbon atom with absorbed hydrogen (b). 
methylene, hydrogen atoms are situated on one line on the opposite sides from a carbon atom by $1.105 \AA$ distance from a carbon atom, and hydrogen atoms cohesion energy is equal to $2.117 \mathrm{eV}$. Methyl represents a planar rectilinear triangle in the middle of which a carbon atom is situated and in the corners hydrogen atoms are located. The distance between carbon and hydrogen atoms is $1.093 \AA$, and hydrogen atom cohesion energy is $2.229 \mathrm{eV}$. Methane represents a rectilinear solid tetrahedron [33], with a carbon atom in the middle and hydrogen atoms in its corners. The distance between carbon and hydrogen atoms is $1.089 \AA$ and hydrogen atom cohesion energy is equal to $2.273 \mathrm{eV}$.

To carry out computer modeling, the Brenner's Code program was used [34]. A computer model of the squareshaped defect-free graphene composed of 112 carbon atoms is also built by the energy minimization method with the use of Brenner potential. Periodic boundary conditions are applied for the graphene plane. Simulation cell normal to graphene plane is considerably bigger to allow movement of molecules and simulation of the adsorption process. Further, interaction forces between graphene and molecules are introduced at $T=0 \mathrm{~K}$. In the process of thermalization, a Nose-Hoover thermostat, NPT ensemble and the heating time at $300 \mathrm{~K}$ were used. As a result, a two-dimensional graphene lattice (Fig. 1a) with the lattice parameter $1.42 \AA$ and cohesion energy of each carbon atom equal to $7.395 \mathrm{eV}$ is observed. These lattice parameters are characteristic of $s p^{2}$ hybridization of carbon bonds in graphene and are in excellent agreement with experimental data [35].

After the computer models of the free hydrogenated molecules $\mathrm{CH}, \mathrm{CH}_{2}, \mathrm{CH}_{3}, \mathrm{CH}_{4}$ and defect-free graphene are built, structures are heated up to $300 \mathrm{~K}$. Then, the deposition of hydrogenated and dehydrogenated carbon atoms on the graphene surface at kinetic energies of 1.0, 1.2, 1.5, 2.3, and $3.1 \mathrm{eV}$ was carried out using molecular dynamics methods. As this process is statistical at room temperature, the site of the deposited molecule on graphene at each deposition energy is studied for 100 numerical runs. Process of deposition of the molecule is random. The initial orientation of $\mathrm{CH}, \mathrm{CH}_{2}, \mathrm{CH}_{3}, \mathrm{CH}_{4}$ molecules relative to graphene is also assigned randomly.

\section{Results and discussion}

According to the results of computer simulation, the binding energy of the single carbon atom, methine, methylene and methyl is more than $1 \mathrm{eV}$. This corresponds to chemisorption, which means that the chemical bonds are generated due to unpaired valent electrons of the incident particles and defect-free graphene. Methane does not have unpaired valent electrons and in the range of investigated deposition energies its chemisorption on graphene is not observed. Methane physical adsorption probability, when binding energy smaller than $1 \mathrm{eV}$ was discussed in detail in [5] by density functional theory methods. The deposited particles $\mathrm{C}, \mathrm{CH}, \mathrm{CH}_{2}, \mathrm{CH}_{3}$ binding probability dependencies are presented in Fig. 2. One can see that these dependencies increase with the deposition energy growth to $2.3 \mathrm{eV}$ and depend on the carbon atom hydrogenation degree: the more the hydrogenation degree the smaller the binding probability.

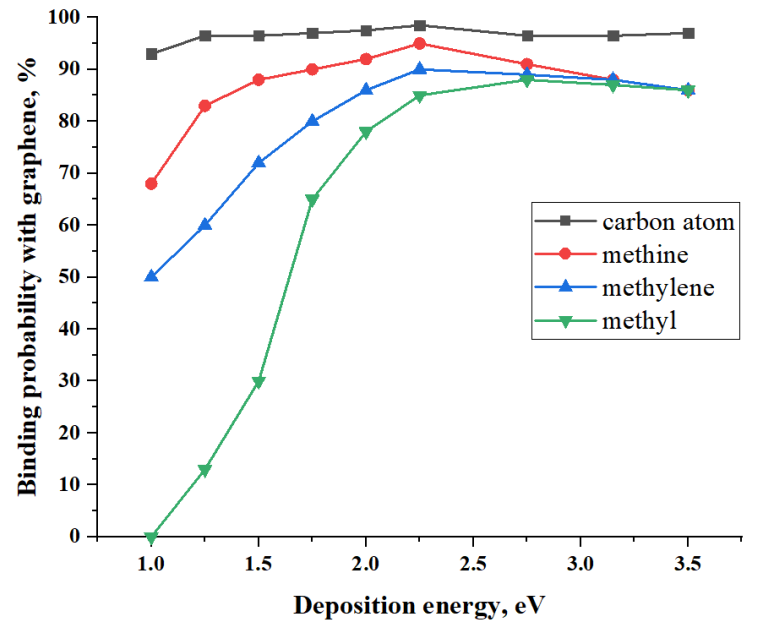

Fig. 2. (Color online) The binding probability of the atom/molecule deposition on graphene as the function of deposition energy.

By means of statistical analysis of the dehydrogenated and short hydrogenated carbon atom deposition probability $P$ dependence from number of its unpaired valent electrons $N$, it is established that this dependence at fixed deposition energy is linear $-P(N)=A \cdot N+C$, where $A$ and $C$ are constants dependent on deposition energy. Their numerical values are presented in Table 1.

Table 1. Linear approximation parameters of the dehydrogenated and short hydrogenated carbon atom deposition probability $P$ dependence from number of its unpaired valence electrons.

\begin{tabular}{|c|c|c|c|}
\hline $\begin{array}{c}\text { Deposition } \\
\text { energy, eV }\end{array}$ & $A, \mathrm{eV}$ & $C, \mathrm{eV}$ & $\begin{array}{c}\text { Maximal relative error of } \\
\text { the approximation, \% }\end{array}$ \\
\hline 1.0 & 23.3 & 0 & $4.9^{*}$ \\
\hline 1.2 & 18.0 & 25.7 & $4.0^{*}$ \\
\hline 1.5 & 10.7 & 53.5 & 2.5 \\
\hline 2.3 & 3.2 & 85.0 & 1.5 \\
\hline 3.1 & 2.8 & 83.5 & 3.5 \\
\hline
\end{tabular}

${ }^{\star}$ Methyl deposition probability is not taken into account in this approximation.

Is also found, that in the cases when the deposited particles are formed the bound state with graphene, these particles are situated near the characteristic points A, B, C and D. Besides, a varying probability exists for bound particle to be situated in these points above the graphene (Table 2). Point A is one of the graphene atoms, point $\mathrm{B}$ is the exact middle between two nearest-neighbor graphene atoms, point $\mathrm{C}$ is the hexagonal geometric middle, point $\mathrm{D}$ is situated between $\mathrm{A}$ and $\mathrm{C}$ points (Fig. 3).

The results show that the interaction of interest occurs only above points $\mathrm{A}$ and $\mathrm{B}$. The impact of oscillatory motions can be estimated from the results shown in Table 2, which show a nonzero (and non 100\%) probability, which indicates the influence of temperature on the scattering process. In the absence of the temperature influence, the values in the columns would be close to 0 or $100 \%$ (for points A and B). For points $C$ and $D$, the impact of temperature is weak, which is explained by the small amplitude of thermal oscillations of atoms by comparison with the bond length. 
Table 2. The number of $\mathrm{C}, \mathrm{CH}, \mathrm{CH}_{2}$ and $\mathrm{CH}_{3}$ molecules that are chemically bonded above the graphene characteristic points. Results are averaged over 100 simulation runs. The highest probability of particles bound on graphene was observed at point $\mathrm{A}$ and the lowest probability at point $\mathrm{E}$.

\begin{tabular}{|c|c|c|c|c|c|c|c|c|c|c|c|c|c|c|c|c|}
\hline \multirow{2}{*}{$\begin{array}{c}\text { The deposited } \\
\text { particle energy, eV }\end{array}$} & \multicolumn{4}{|c|}{ Above the point $\mathrm{A}$} & \multicolumn{4}{|c|}{ Above the point B } & \multicolumn{4}{|c|}{ Above the point $\mathrm{C}$} & \multicolumn{4}{|c|}{ Above the point $\mathrm{D}$} \\
\hline & $\mathrm{C}$ & $\mathrm{CH}$ & $\mathrm{CH}_{2}$ & $\mathrm{CH}_{3}$ & $\mathrm{C}$ & $\mathrm{CH}$ & $\mathrm{CH}_{2}$ & $\mathrm{CH}_{3}$ & $\mathrm{C}$ & $\mathrm{CH}$ & $\mathrm{CH}_{2}$ & $\mathrm{CH}_{3}$ & $\mathrm{C}$ & $\mathrm{CH}$ & $\mathrm{CH}_{2}$ & $\mathrm{CH}_{3}$ \\
\hline 1.0 & 76 & 61 & 42 & 0 & 7 & 6 & 7 & 0 & 7 & 0 & 0 & 0 & 4 & 0 & 0 & 0 \\
\hline 1.2 & 92 & 78 & 49 & 14 & 3 & 5 & 11 & 0 & 0 & 0 & 0 & 0 & 0 & 0 & 0 & 0 \\
\hline 1.5 & 93 & 66 & 57 & 65 & 1 & 21 & 16 & 0 & 0 & 0 & 0 & 0 & 0 & 0 & 0 & 0 \\
\hline 2.3 & 93 & 57 & 71 & 89 & 3 & 36 & 19 & 0 & 0 & 2 & 0 & 0 & 0 & 0 & 0 & 0 \\
\hline 3.1 & 84 & 49 & 64 & 88 & 8 & 35 & 24 & 0 & 3 & 5 & 0 & 0 & 1 & 1 & 0 & 0 \\
\hline
\end{tabular}

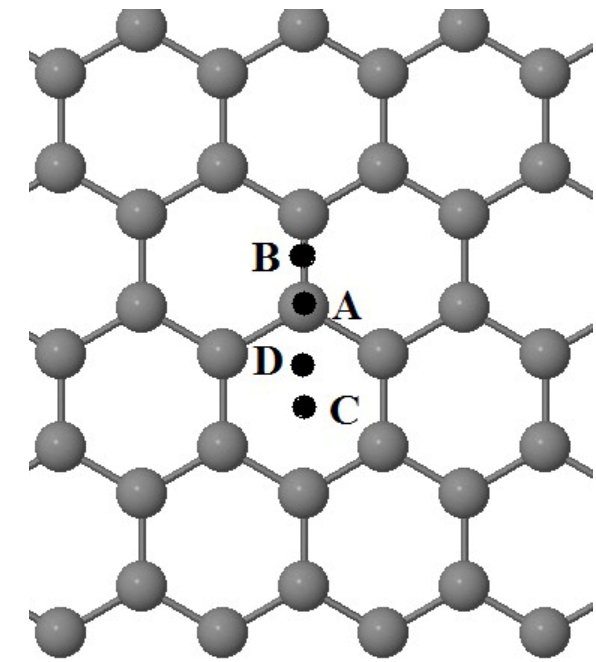

Fig. 3. Points $\mathrm{A}, \mathrm{B}, \mathrm{C}$ and $\mathrm{D}$ are the graphene characteristic points which are closely located to the fixed $\mathrm{C}, \mathrm{CH}, \mathrm{CH}_{2}$ и $\mathrm{CH}_{3}$ particles after their deposition on graphene.

\section{Conclusion}

In conclusion, it was found by molecular dynamics simulation that the deposition processes of the hydrogenated and dehydrogenated carbon atoms on defect-free graphene depend on the degree of hydrogenation of carbon atoms. It was shown that the higher the hydrogenation degree of the carbon atom, the smaller its chemisorption probability on graphene. Methane as a fully hydrogenated carbon atom does not undergo chemisorption on graphene at deposition energies from 1 to $3.1 \mathrm{eV}$. We also established that in the cases when the deposited particles formed the bound state with graphene, then these particles are situated near the characteristic points A, B, C and D. Besides, a varying probability exists for a bound particle to be situated in these points above the graphene. It was also established that the maximum probability of $\mathrm{C}, \mathrm{CH}$, $\mathrm{CH}_{2}$ and $\mathrm{CH}_{3}$ chemisorption on graphene must be observed at their deposition energy near $2.3 \mathrm{eV}$.

Acknowledgements. This work was done with the financial support of grant No. OT-F2-46 provided by Arifov Institute of Ion-Plasma and Laser Technologies.

\section{References}

1. A. K. Geim, K. S. Novoselov. Nature Mater. 6, 183 (2007). $\underline{\text { Crossref }}$
2. Y. Zhang, Y.-W. Tan, H. L. Stormer, P. Kim, et al. Nature. 438, 201 (2005). Crossref

3. K.S. Novoselov, Z. Jiang, Y. Zhang, et al. Science. 315 (5817), 1379 (2007). Crossref

4. K. S. Novoselov, A. K. Geim, S. V. Morozov, et al. Nature. 438 (7065), 197 (2005). Crossref

5. K. Wang, M. Xu, Y. Gu, et al. Nano Energy. 31, 486 (2017). Crossref

6. R. Gholizadeh, Y.-X. Yu. J. Phys. Chem. C. 118, 28274 (2014). Crossref

7. R. Gholizadeh, Y.-X. Yu. Appl. Surf. Sci. 357, 1187 (2015). $\underline{\text { Crossref }}$

8. Y.-X. Yu. Phys. Chem. Chem. Phys. 15, 16819 (2013). Crossref

9. A. Hussain, S. Ullah, M. A. Farhan, M. A. Saqlain, F. Sato. New J. Chem. 41, 10780 (2017). Crossref

10. R. Gholizadeh, Y.-X. Yu, Y. J. Wang. Appl. Surf. Sci. 420, 944 (2017). Crossref

11. A. M. Bayoumy, H. Elhaes, O. Osman, K. T. Kholmurodov, T. Hussein, M. A. Ibrahim. Biointerface Res. Appl. Chem. 10 (1), 4837 (2020). Crossref

12. S. Maruyama, Y. Miyauchi, T. Edamura, Y. lgarashi, S. Chiashi, Y. Murakami. Chem. Phys. Lett. 375, 553 (2003). Crossref

13. F. V. Ferreira, M. Mariano, L. S. S. Lepesqueur, I. F. Pinheiro, L. G. Santos, J. Burga Sanchez, D. H. S. Souza, C. Y. KogaIto, et al. Mater. Sci. Eng. C. 98, 800 (2019). Crossref

14. O. Lehtinen, N. Vats, G. Algara-Siller, P. Knyrim, U. Kaiser. Nano Lett. 15 (1), 235 (2015). Crossref

15. A.A. Dzhurakhalov, V.G. Stelmakh, N.Yu. Turaev, I. D. Yadgarov. Uzbek Physical Journal. 17 (6), 400 (2015).

16. V.G. Stelmakh, I. D. Yadgarov. Letters on Materials. 9 (3), 344 (2019). (in Russian) [В.Г. Стельмах, И.Д. Ядгаров. Письма о материалах. 9 (3), 344 (2019).] Crossref

17. B.C. Wood, Sh.Y. Bhide, D. Dutta, V.S. Kandaga, A.D. Pathak. Journal of Chemical Physics. 137, 054702 (2012). Crossref

18. D.V. Alyabev, I.D. Yadgarov, M.Sh. Kurbanov, A.N. Ulukmuradov, V.G. Stelmakh. J. Phys.: Conf. Ser. 1686, 012060 (2020). . Crossref

19. H. J. Li, D. J. Qian, M. Chen. ACS Appl. Mater. Interfaces. 7, 25162 (2015). Crossref

20. K.R. Reddy, C.H.V. Reddy, M.N. Nadagouda, et al. J. Environ. Manage. 238, 25 (2019). Crossref

21. H. Enamul, Y. Yusuke, M. Victor, et al. Chem. -Asian J. 13, 3561 (2018). Crossref

22. T. Ueno, T. Yoshioka, J. i. Ogawa, et al. Synth. Met. 159, 2170 (2009). $\underline{\text { Crossref }}$ 
23. P. A. Denis. Chem. Phys. Lett. 492 (4-6), 251 (2010). Crossref

24. H. G. Shiraz, O. Tavakoli. Renew Sustain Energy Rev. 74, 104 (2017). Crossref

25. D. W. Boukhvalov, M.I. Katsnelson, A.I. Lichtenstein. Phys Rev B. 77, 035427 (2008). Crossref

26. D. C. Elias, et al. Science. 323 (5914), 610 (2009). Crossref

27. S. Patchkovskii, et al. Proc Natl Acad Sci USA. 102 (30), 10439 (2005). Crossref

28. D.W. Brenner, O.A. Shenderova, J.A. Harrison, S. J. Stuart, B. Ni, S. B. Sinnot. J. Phys: Condens. Matter. 14, 783 (2002). $\underline{\text { Crossref }}$
29. D. P. Kosimov, A. A. Dzhurakhalov, F. M. Peeters. Phys Rev B. 78, 235433 (2008). Crossref

30. Y. Yamayose, Y. Kinoshita, Y. Doi, A. Nakatani, T. Kitamura. Europhys Lett. 80, 40008 (2007). Crossref

31. Q. Lu, M. Arroyo, R. Huang. J Phys D Appl Phys. 42, 102002 (2009). Crossref

32. C. D. Reddy, S. Rajendran, K. M. Liew. Nanotechnology. 17, 864 (2006). Crossref

33. A. A. Dzhurakhalov, F.M. Peeters. Carbon. 49, 3258 (2011). Crossref

34. D. W. Brenner. Phys. Rev. B. 42, 9458 (1990). Crossref

35. V.K. Tewary, B. Yang. Phys Rev B. 81, 039904 (2009). Crossref 